\title{
EXPLORING THE RESILIENCE MOVEMENT THROUGH AN URBAN \\ PLANNING AND WATER MANAGEMENT LENS
}

\section{By}

\section{Mariya Gorlova}

H.B.A., University of Toronto, 2016

A Major Research Paper

$$
\text { presented to Ryerson University }
$$

in partial fulfillment of the requirements for the degree of

\author{
Master of Planning \\ in the program of \\ Urban Development \\ Toronto, Ontario, Canada, 2018
}

(C) Mariya Gorlova, 2018 


\section{Author's Declaration}

I hereby declare that I am the sole author of this MRP. This is a true copy of the MRP, including any required final revisions.

I authorize Ryerson University to lend this MRP to other institutions or individuals for the purpose of scholarly research

I further authorize Ryerson University to reproduce this MRP by photocopying or by other means, in total or in part, at the request of other institutions or individuals for the purpose of scholarly research.

I understand that my MRP may be made electronically available to the public. 


\title{
EXPLORING THE RESILIENCE MOVEMENT THROUGH AN URBAN PLANNING AND WATER MANAGEMENT LENS
}

\author{
(c) Mariya Gorlova, 2018 \\ Master of Planning
}

in

\section{Urban Development}

\begin{abstract}
Land use planning recognizes the need for incorporating climate change adaptation strategies to address natural disaster reoccurrence. In 2013, the Rockefeller Foundation developed the 100 Resilient Cities (100RC) model to support initiatives related to climate change and resilience. Globally through the model, cities appointed Chief Resilience Officers (CROs) to develop a vision, lead implementation and establish long-term city resilience. Three major cities in Canada (Toronto, Vancouver and Montreal) are now RC100 cities and subsequently introduced the positions of CROs. The purpose of this research paper is to highlight the current state of interventions in Toronto water management strategies to emphasize the role land use planning can have in Resilience Strategy development. Recommendations will be made based on literature review, policies and best practices scan, as well as stakeholders' interview analysis. Safety and wellbeing of citizenry are at the forefront of the urban agenda, requiring utmost attention to climate change and precautionary measures against natural disaster.
\end{abstract}

Key words: land use planning, urban water management, Canada, resilient cities 


\section{Acknowledgements}

I would like to thank my Supervisor, Nina-Marie Lister, for the support, guidance, and knowledge that she provided throughout the course of this Major Research Paper.

A special thank you is extended to Christopher De Sousa, my second reader, for his advice, thoughtful feedback, and encouragement.

My most sincere gratitude goes out to Louise Bradette, Elliott Cappell, Katherine McPherson, as well as their hardworking teams, for making the time to speak with me about their work. 


\section{Table of Contents}

Abstract

.iii

Table of Contents

$\mathrm{v}$

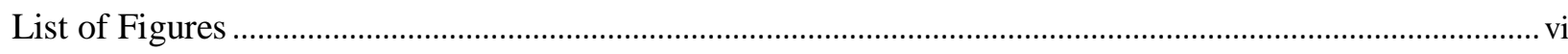

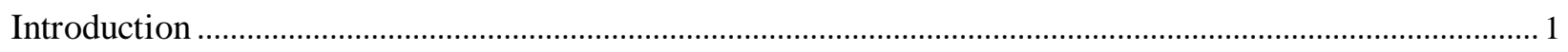

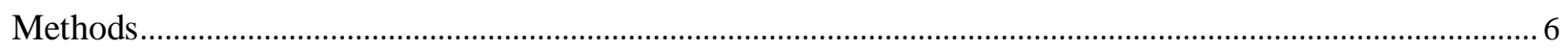

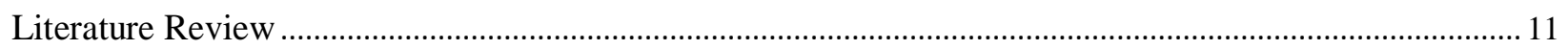

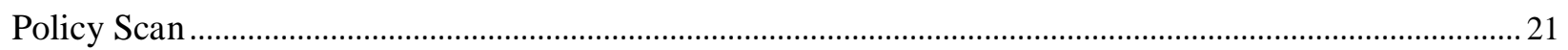

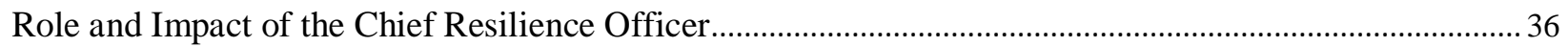

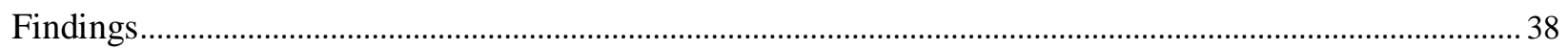

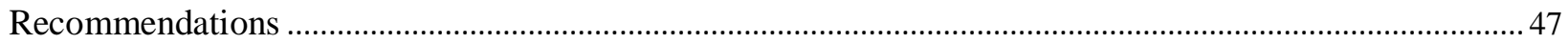

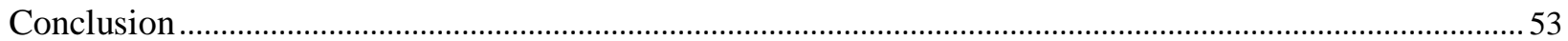

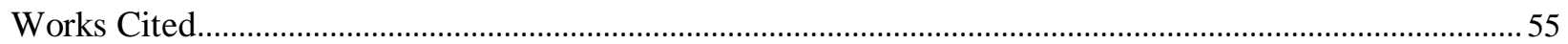




\section{List of Figures}

Figure 1: Map depicting extent of destruction caused by Hurricane Hazel....................... 2

Figure 2 Illustration of effect of development on stormwater ........................................ 3

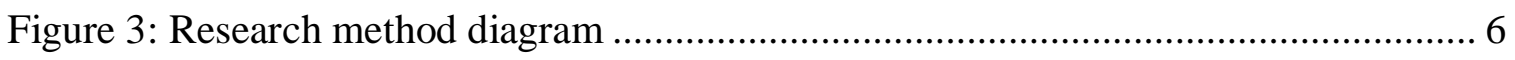

Figure 4: Illustration of engineering resilience (left) and ecological resilience (right)... 13

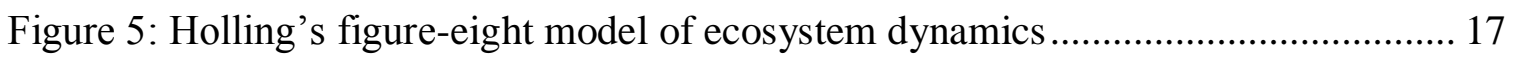

Figure 6: Visual representation of policies used in research ...................................... 22

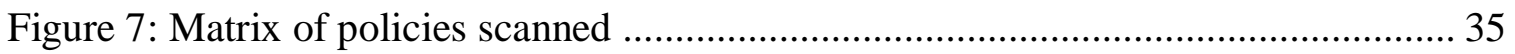

Figure 8: Proposed strategy for collaboration and structure ...................................... 37

Figure 9: Illustration of natural and urban stormwater drainage ................................. 42 


\section{Introduction}

The topic of resilient cities is a timely one due to the increase in frequency of disaster occurrence in urban areas. Recently, several Canadian cities appointed Chief Resilience Officers (CROs), whose role is to establish municipal resilience to natural disasters through the creation of a Resilience Strategy (RC100, n.d.). Their roles are largely needed due to the global trends of urbanization in the face of climate change. The main focus of resilience is to increase adaptation practices associated with natural disasters, specifically events related to climate change. Flood and water management is of crucial importance to every city in order to ensure safety and wellbeing of citizenry.

Historically, there have been a number of extreme stormwater flooding events with catastrophic consequences in the Greater Toronto Area (GTA). In 1954, Hurricane Hazel affected the GTA, with flooding to major watersheds (Environment and Climate Change Canada (ECCC), 2013). Over 80 people died, almost nineteen hundred became homeless, and the overall estimated damage was nearly one billion dollars (Isai, 2016). See Figure 1 for a visual representation (Government of Canada, 2010). Following the event, for the first time land use planners implemented land preparation strategies for similar flooding reoccurrence. The Toronto and Region Conservation Authority (TRCA) was established to oversee watershed management and sustainability practices (ECCC, 2013). More recently in June 2017, Toronto received funding for the establishment of a $\mathrm{CRO}$ in order to enhance municipal resilience in times of natural disasters (City of Toronto, n.d.). 


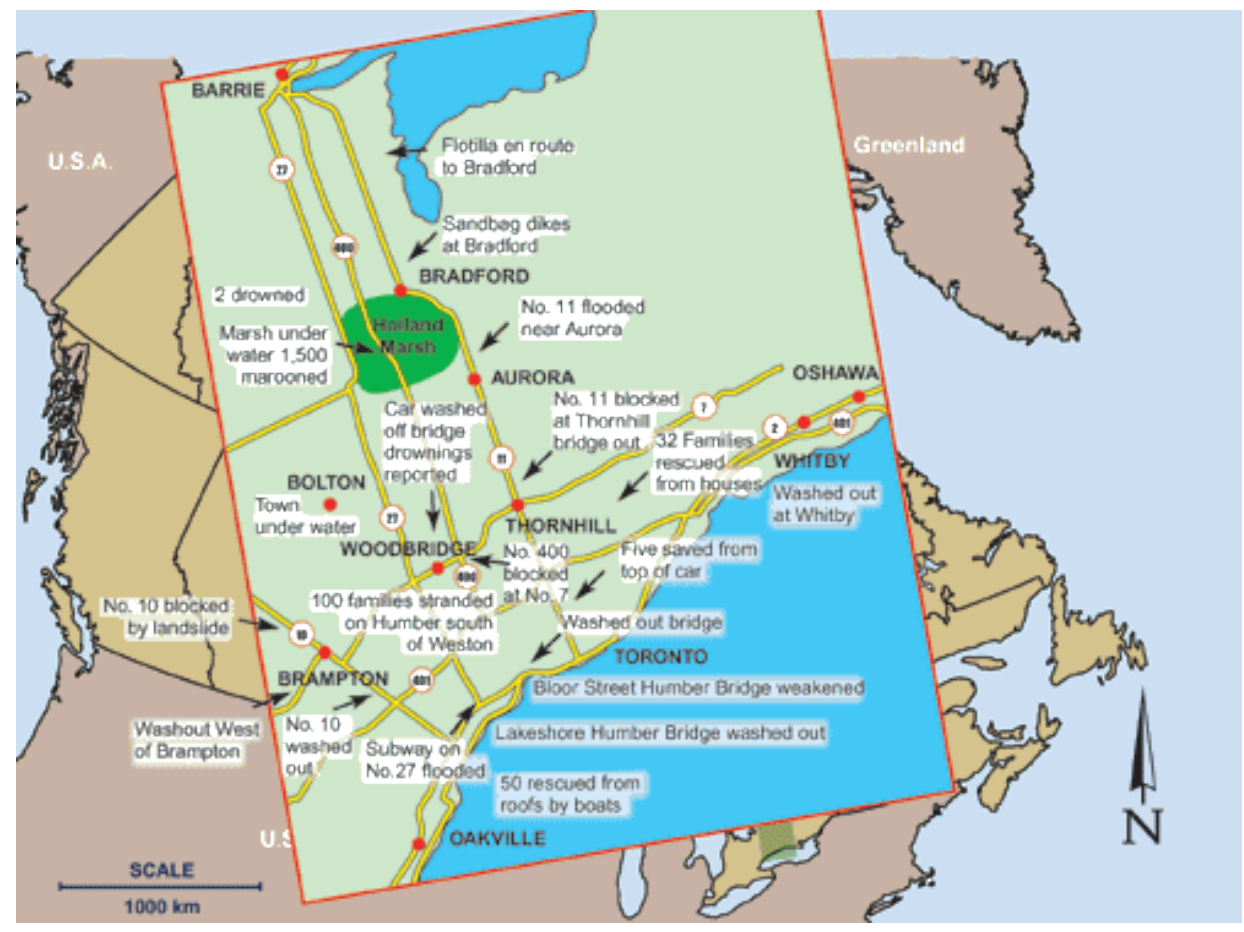

Figure 1: Map depicting extent of destruction caused by Hurricane Hazel

The role of the $\mathrm{CRO}$ is arguably critical to the planning and implementation of the Resilience Strategy pertaining to natural disaster management. Empey (2017) highlighted that the $\mathrm{CRO}$ position can be a champion of integrative and adaptive governance to bridge any fragmented system potentially existing within municipal governance. Empey (2017) recommended that the Resilience Strategy (also referred to as "the Strategy" throughout this paper) intersects with land use planning tools to ensure longevity and implementation. Alone, the Resilience Strategy serves as a guideline for the municipality. With the incorporation of land use planning tools, the Strategy has the ability to become more robust due to the legislative and regulatory nature of planning mechanisms. Therefore, close collaboration of the $\mathrm{CRO}$ and land use planning is beneficial to ensure longevity and implementation of the Strategy. 


\section{Research Problem}

Stormwater is defined as the rainfall and snowmelt that seeps into the ground or runs into storm sewers, streams, and lakes (Ministry of the Environment, 2016). The hydrologic cycle naturally acts to continuously circulate water between the atmosphere and the land. Increased urban development in Toronto has caused a rise in stormwater runoff due to increased imperviousness (see Figure 2).

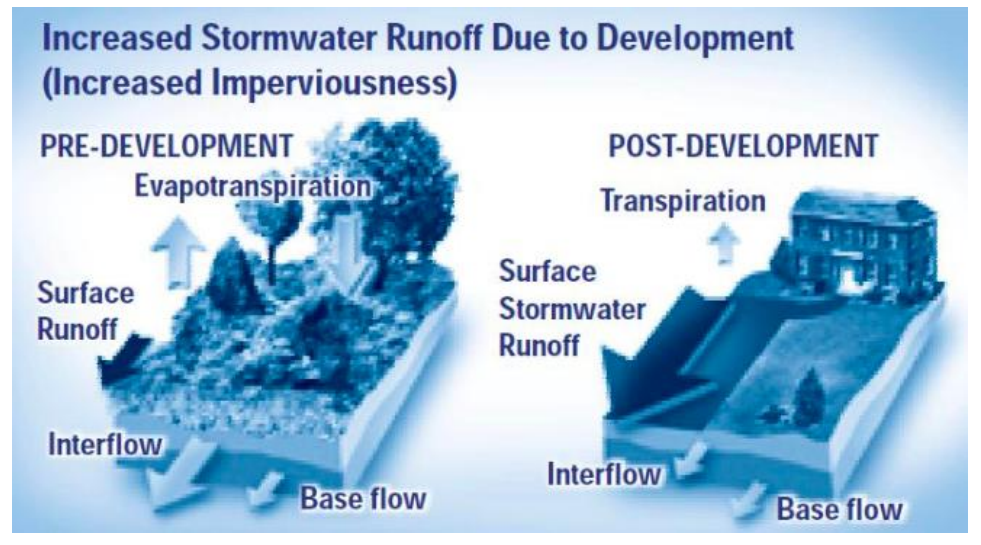

Figure 2: Illustration of effect of development on stormwater

(Source: Ministry of the Environment)

Historically, stormwater management has been targeted by Toronto Water and the TRCA through flood control structures and facilities (City of Toronto, n.d.; TRCA, n.d.). See Figure 2 for the location of flood structures operated by the TRCA. A window of opportunity exists for planning policy to intervene in stormwater management in order to provide a comprehensive set of solutions which can include land use planning strategies and policies. With increased frequency of stormwater flooding, it is urgent that this problem is addressed. The $\mathrm{CRO}$ has the potential to create a stronger intersection in the way that land use planning targets stormwater management through the Toronto Resilience Strategy. 


\section{Research Question}

The question that this MRP seeks to address is - what are the planning policies specific to stormwater management that intersect with the City of Toronto Resilience Strategy? This question is significant because the Resilience Strategy is a new framework that is being introduced in Toronto, and it has the capacity to target ways that stormwater management can be improved. This enquiry is significant because planning policies have the ability to enhance the Resilience Strategy in relation to water management with legislative tools and a policy implementation process. Consequently, it is important to identify the ways in which urban water management is currently identified throughout planning policy in Toronto. In addition, the purpose of this research is to identify how the work that the CRO undertakes can be supported in order to ensure that a lasting impact of resilience is established and upheld in Toronto.

\section{Research Objectives}

The focus of this research is to pinpoint joint endeavors in the professional portfolios of the $\mathrm{CRO}$, urban water management policies, and land use planning in Toronto. The objective of this paper is to see what stormwater management practices currently exist in the City of Toronto, and highlight the role that the Resilience Strategy can play in addressing the concerns of flooding with the assistance of land use planning. The investigations presented in this MRP strive to generate concise conclusions in the following research objectives:

1. Understand the role of the RC100 Office and its intersection with stormwater management planning policies in the City of Toronto; 
2. Reveal the potential of tools that the Toronto Resilience Strategy can work with through a policy scan that focuses on planning policies that exist surrounding stormwater management in Toronto;

3. Uncover what lessons can be learned from the work of the CROs of Montreal and Vancouver through best practice interviews; and

4. Provide recommendations for how land use planning tools and policies can be used to further the Toronto Resilience Strategy.

\section{Contribution to planning}

There is a strong need for the role of the CRO to intersect with the field of land use planning. This is because the intersection of the role with the municipal planning department presents the opportunity to impact development and green infrastructure in order to make the Resilience Strategy grounded in policy that is required to be enforced. It is vital to ensure collaboration across municipal government departments in order to make certain that there is a cross-disciplinary approach to risk mitigation and ensuring that there are exemplary tasks undertaken to have resilient cities.

The topic of resilient cities, the role of the $\mathrm{CRO}$, and its relation with planning is crucial in addressing values set out by the Canadian Institute of Planners' Statement of Values, such as: the need to respect and integrate the needs of future generations, the need to value the natural and cultural environment, and the need to recognize and react positively to uncertainty (Canadian Institute of Planners, n.d.). 


\section{Methods}

In order to undertake this study to explore the role that land use planning can play in assisting the work of the RC100 Office in Toronto, a combination of primary and secondary sources were used to conduct research on resilience in the City of Toronto as a case study. Research commenced with a literature review which focused on the theory and practice of resilience. This set the foundation for a policy scan that focused on reviewing guidelines surrounding urban water management in the City of Toronto for language surrounding climate change adaptation. In particular, an emphasis is placed on seeing what role this language has in the context of resilience and its intersection with land use planning.

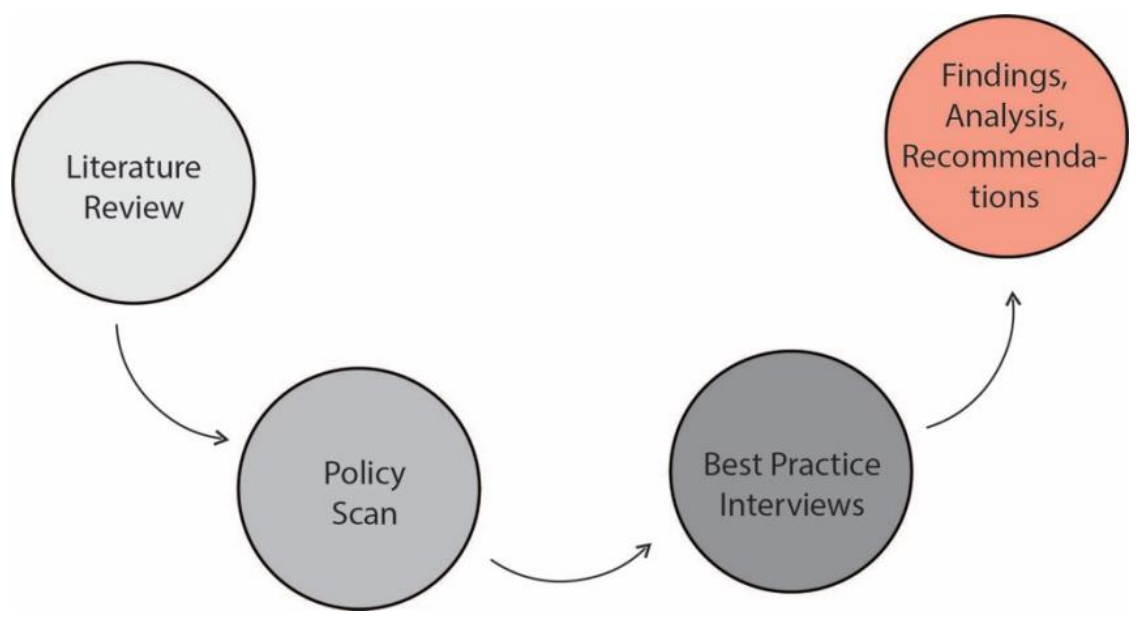

Figure 3: Research method diagram

Policy scans are frequently used within academic research to survey existing policies in specific areas of interest in order to inform existing and future policy development work (Connecticut Department of Public Health, 2014). In preparation for a policy scan, the objective(s) and scope must be defined (Connecticut Department of 
Public Health, 2014). This research sought to identify how Toronto is currently implementing stormwater management through the lens of resilience. While traditionally search terms are used in policy scans, this MRP focused on reviewing policy for language surrounding applied resilience and climate change adaptation. The data sources that were identified included the Toronto Official Plan, Toronto Water Strategy, Ontario Ministry of the Environment, and the Provincial Stormwater Management and Design Manuel. An analysis of how each data source incorporated applied resilience and climate change adaptation was undertaken.

Prior to conducting primary research, a Research Ethics Board (REB) application was filed in order to ensure that research was conducted in an ethical manner. A full-scale REB review was not required, as the principal research method used was a qualitative interview approach that focused on people who in the course of their daily lives comment on matters surrounding stormwater management and planning policies in their professional capacity. The research method determined that such interviews would be vital to the research conducted due to the up-to-date information and insights that would be provided. Material that was submitted to the REB included an interview guide with an explanation provided that the interviews would be semi-structured and were approximately thirty minutes in length and conducted over the phone. Additionally, the application included the preamble for the ethics process involved for the participants. The preamble also outlined whether the subjects would be allowed to be quoted by their name. All participants consented to be quoted by name. The preamble was accompanied by a semi structured interview guide which listed the questions that would be asked during the interview. 
After obtaining an approval for a short-review ethics application submission to the Ryerson University REB, primary research on the project commenced which involved semi-structured qualitative interviews with the Chief Resilience Officers of Montreal (Louise Bradette), Toronto (Elliott Cappell), and Vancouver (Katherine McPherson) in February 2018. These respondents were chosen through expert purposive sampling. Purposive sampling focuses on the judgement of the researcher to focus on a sample size that allows information-rich informants to address the research questions (Duan et al., 2015). Expert sampling is a form of purposive sampling that is used when research requires knowledge from individuals with particular expertise (Alkassim et al., 2016). The CROs of Montreal and Vancouver were chosen to be interviewed because they are categorized as major cities well as their recent experience with flooding events that have been linked to increased rainfall. Additionally, an Urban Lands Institute (ULI) discussion featuring the Chief Resilience Officer of Toronto in February 2018 provided a strong knowledge base for ensuring a strong understanding of the development of Toronto's Resilience Strategy.

An analysis of the qualitative interviews was then conducted in order to explore the role that land use planning plays in furthering the work of the RC100 Office in the City of Toronto as it relates to stormwater management. This provided a strong foundation for assessing the role and impact of the Chief Resilience Officer in relation to water management and the realm of urban planning, presenting key findings on the intersection between the RC100 Office in Toronto and municipal planning, and providing recommendations on how land use planning can aid the work of progressing the vision of resilience as it pertains to stormwater management. 
The research conducted in this study can be defined as qualitative, exploratory research. The foundation of qualitative research involves seeking to understand a social phenomena within a natural setting by systems of inquiry that are not statistical procedures (Robson \& Neuman, 2008). Exploratory research focuses on reporting the background or context of a phenomenon that has not been examined before (Robson \& Neuman, 2008). A key word search using the Ryerson University Library \& Archives, SAGE Journals, and JSTOR databases revealed that there was no previous literature written on the topic of Canadian CROs and how their work intersects with municipal planning and stormwater management. This is largely due to the position being new, as the first Canadian CRO was introduced in 2016 (Kovacs, 2017). Consequently, an exploratory approach was chosen in order to explore this new area of research and establish a foundation for future studies that are more systematic and extensive.

The time dimension of this research was cross-sectional in order to interview a collection of subjects at one time (Robson \& Neuman, 2008). This method provides the means for learning from professionals that hold the title of CRO in major Canadian cities that are further along the Resilience Strategy in order to provide recommendations for Toronto. While the cross-sectional approach is the simplest and least costly alternative to conducting a study, it has the limitation of providing minimal opportunity for reviewing social processes or changes (Robson \& Neuman, 2008). It is also limited to a one time discussion, and consequently the timing of the interview could influence the quality of the data.

The primary data collection technique used was the semi-structured qualitative interview, in order to gain an in-depth understanding of a social phenomenon from a 
small group of people (Robson \& Neuman, 2008). The social phenomena that was examined in this study were the CROs of Montreal, Toronto, and Vancouver in order to gather insight into their professional experience with stormwater management and municipal planning. The semi-structured qualitative interview allows interviewees to answer questions on their own terms compared to structured interviews, while still providing guidance for comparison across interviewees in a study by focusing on the same topics and questions (Edwards \& Holland, 2013). The interview questions pertained to the professional work of the interviewee. The interviews were conducted over the phone, and were no greater than 30 minutes in length. There were four main questions that were asked in each interview. Each interview was recorded, transcribed, and stored for two years.

The research theory that was foundational in this study was descriptive phenomenology, which is an inductive qualitative research tradition fathered by the $20^{\text {th }}$ century philosophies of Husserl (Reiners, 2012). The methods of phenomenological inquiry seek to articulate the meaning of experienced phenomena, rather than to measure them (Barr et al., 2017). Husserlian descriptive phenomenology aims to explore and describe lived experience (Barr et al., 2017). This research targeted the exploration of the professional experience of the CROs.

Although this study was designed with the intention of being comprehensive in its approach to understanding the work of the Toronto CRO through the incorporation of both primary and secondary research, it is also vital to address research limitations. The time constraint that this work was performed under posed as the primary constraint to attaining a more complete understanding of the work of the RC100 Office in Toronto. 
Such an understanding could have been furthered through conducting focus group interviewing sessions with professionals that work closely with the Chief Resilience Officer of Toronto in order to ensure a broader understanding of the intersection between resilience, storm water management, and municipal planning in Toronto. The individuals that could have contributed to a further pursuit of such research include those that sit on the internal resilience city working group and municipal city planners that are involved in policy research surrounding resilience.

\section{Literature Review}

The literature review conducted for this research paper is predicated upon an analysis of resilience from theoretical and practical perspectives in order to set a benchmark for understanding what role resilience plays in urban areas such as Toronto. In this section, the analysis and synthesis of scholarly literature relevant to the main concepts of the study are provided. The literature search was primarily conducted using the Ryerson University Library \& Archives database with key terms such as resilience, engineering resilience, ecological resilience, urban hazard mitigation, urban water management, combined with urban planning. The results were limited to the English language. Additionally, popular online sources dating from 2010 to 2018 were used, including the RC100 and Arup website. 


\section{Theory}

The concept of resilience has a strong grounding within theoretical academic literature. Addressing the origins of the concept is vital in order to reveal how the concept evolved over the course of time, and to see its relation and present connections with land use planning and governance systems. This provides a strong framework for understanding the theory of practice within resilience in relation to $\mathrm{RC} 100$, and the role of the Chief Resilience Officer.

\section{What is resilience?}

The concept of resilience stems from the disciplines of psychology, disaster relief and military defense, engineering, and ecology. Across these disciplines, the concept of resilience is generally characterized by the principle of being flexible and adaptable to change (Lister, 2016). In order to discuss resilience in the context of urban systems, it is vital to discuss the evolution of the core meaning from the equilibrium paradigm to the contemporary ecological paradigm.

The equilibrium paradigm is seen as the ability of a system to return to its former equilibrium state following a disturbance (Peterson et al., 1998). Within academic literature, this framework is generally seen as being characterized by stability, a single point of equilibrium, and the permanence of a system. It is consequently often referred to as "engineering resilience" and/or "traditional resilience" due to the focus of a desired state of stability which is required in tasks such as bridge building (Holling, 1996).

A shift in thinking of resilience occurred in the 1970s when it was acknowledged that it is important for systems to be flexible and have the capacity to withstand 
adjustments to external disturbances, including natural disasters such as flooding (Clark et al. 1979; Folke, 2006; Holling, 1973; Ludwig et al., 1978). A drawback for examining such problems with an exclusive equilibrium viewpoint is that there is minimal insight provided into the behaviour of systems that are not near an equilibrium state (Holling, 1973). This is often named ecological resilience as it is founded upon a non-equilibrium view of resilience, which means that a system is unable to return to a fixed, stable point or level following a disturbance but rather must make adjustments to changing conditions (Pickett et al., 2014; Resilience Alliance, n.d.). This can be illustrated in Figure 4, where engineering resilience is showcased on the left in a closed system, while ecological resilience is depicted in an open system showcasing a metastable equilibrium on the right (adopted from Desjardins et al., 2015). The dashed arrows indicate disaster-caused perturbations. Knowledge of the paradigm shift that occurred between traditional resilience and ecological resilience is vital in order to understand its relationship with urban systems.

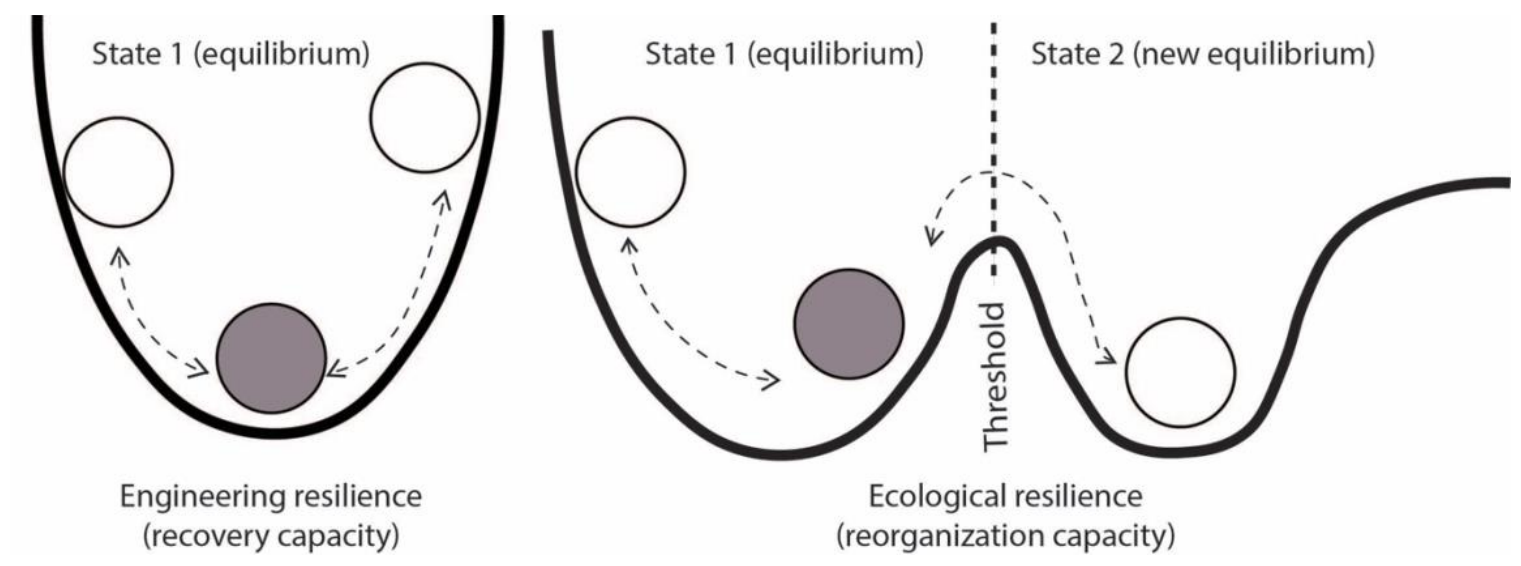

Figure 4: Illustration of engineering resilience (left) and ecological resilience (right). 
Holling (1973) identified that stability and resilience are key indicators in the behaviour of ecological systems. Stability is defined as "the ability of a system to return to an equilibrium state after a temporary disturbance; the more rapidly it returns to an equilibrium state after a temporary disturbance; the more rapidly it returns and the less it fluctuates, the more stable it would be," while resilience is defined as "a measure of the persistence of systems and of their ability to absorb change and disturbance and still maintain the same relationships between populations or state variables" (p.14). Holling makes the distinction that these two definitions can allow systems to be resilient while still allowing for fluctuation.

There has been a trend in recent academic articles to incorporate design and planning related approaches into ecological design. Lister (2016) postulated that there has been a growing response to the increase of major storm events. In addition, this has included the development of political rhetoric that addresses resilience in the face of vulnerability (Lister, 2016). However, there is often a lack of coordinated governance, benchmarks, and policy applications that relates to climate change adaptation. Consequently, it is stated that land use planners and design-related implementations can have a great impact on resilience implementation as a result of the tools that are made available to them as they relate to key principles of adaptive complex systems.

There are several design-related approaches in relation to water management that arise from a vision of applied ecological resilience. These approaches focus on a reaction to flood adaptation and an understanding that in a healthy ecosystem there needs to be an understanding that planning for change to occur is a necessity. The foundation of a design approach to addressing the problem of flooding through a resilience perspective is that an 
analysis of a water system must be performed from multiple perspectives and scales, that allows for additional expert involvement. This allows for the role of the expert to be incorporated. Secondly, it is vital to ensure that there is a connection across scales and variance, which ensures the tightness and rigidity of the feedback loop. Thirdly, the ecosystem must be planned in a variety of states. Lastly, it is important to allow for diversity and allow for a system to ensure that it is safe to fail at small scales.

Such design-related approaches showcase the importance of understanding the theory of ecological resilience. Within the application of this theory, it translates into the fundamental principal that there is no single point of equilibrium when considering design approaches to addressing stormwater flooding. Instead, with greater changes to the urban ecosystem due to climate change it will be vital to address that there will be a likelihood of future floods and major stormwater events in planning policy and design interventions. Such events showcase the importance of recognizing that it is vital that the fundamental baseline for planning policies and design interventions is to recognize that the urban system must be able to absorb change and disturbance, which in this instance is stormwater flooding.

\section{How is resilience related to sustainability and other long-term goals for urban living?}

The world is rapidly urbanizing. In 2018, it was predicted that over $55 \%$ of the human population lives in urban areas. Estimates indicate a possible increase to $68 \%$ by 2050 (United Nations, 2018). Such rapid urbanization impacts vegetated surfaces which provide evaporative cooling, rainwater interception, storage and infiltration functions. 
Consequently, it will be vital to incorporate adaptive and mitigative measures in order to address resulting climatic stressors that municipalities will encounter to enhance the sustainable development of urban areas with population growth.

\section{How does resilience affect planning and flooding specific policies?}

Lu and Stead (2013) identified that there is a greater push towards cities considering adaptive strategies rather than investment in defense projects in cities. Within adaptive strategies, the approach of urban resilience and resilience planning have gained popularity due to their ability to provide more adaptive and flexible approaches in decision making (Lu \& Stead, 2013). Literature linking land use planning with resilience strategies first appeared in the 1990s (Mileti, 1999). Within this early literature, the definition of resilience followed the equilibrium view as it placed emphasis on the ability of a social system to withstand disturbances and reorganize itself following a disturbancedriven change (Walker et al., 2002). The first strategies that were placed focused on local preparation and mitigation actions. This coincides with the ability of land use planning to separate land uses in order to reduce the risk of possible disturbances, such as locating developments away from flood-prone areas.

The inclusion of the adaptive cycle theory within resilience focuses on system dynamics (such as ecosystems, societies, and economies) without an equilibrium condition, but rather repeatedly "go through" the following four characteristic phases of growth and exploitation; conservation; collapse or release; and renewal and reorganization (Fath et al., 2015; Holling, 1986). Disturbances to the system dynamics of 
a municipality can be considered to be threats, however also present themselves as opportunities to improve the health and the ability of a system to re-organize. See Figure 5 for a visual representation (adapted from Fath et al., 2015).

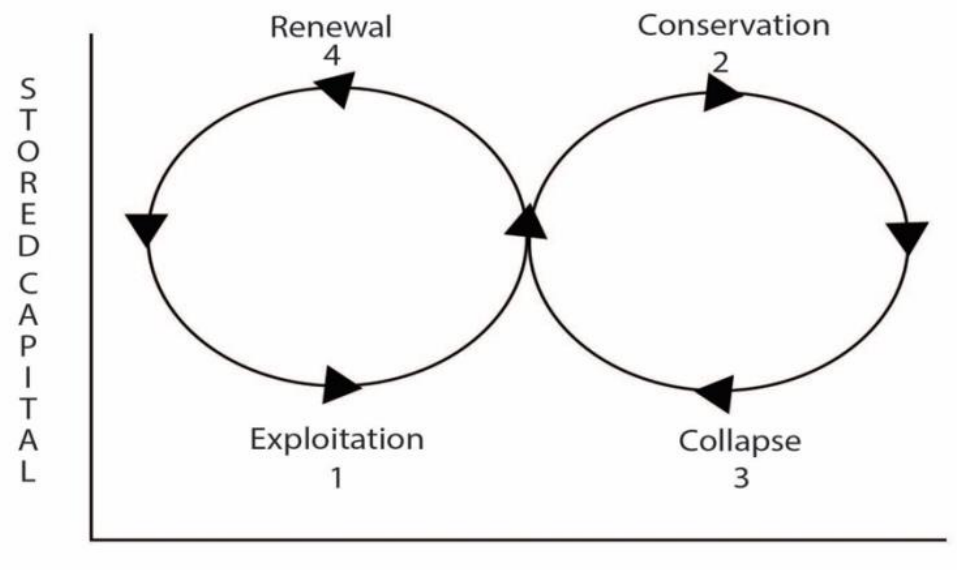

CONNECTEDNESS

Figure 5: Holling's figure-eight model of ecosystem dynamics

Lu and Stead (2013) stated that within the adaptive cycle theory, resilience can be expressed as the robustness and rapidity of a system. The authors defined that the robustness of a system is determined by its strength to carry and absorb disturbances while rapidity is defined by the flexibility of a system to rearrange itself to a new stable state. Reactions (related to system rapidity) in disturbance management can include city and drainage system response, damage repairs, financial support, and future improvements of urban infrastructure. Additionally, there has also been the notion that resilience also has the qualities of redundancy, diversity, efficiency, autonomy, strength, interdependence, adaptability, and collaboration (Godschalk, 2003). When it comes to resilience, inland flood risk management, and policy-making, the Dutch city of 
Rotterdam provides a good empirical study that other cities can learn from, because spatial planning played a large role in providing land use strategies in order to offer more water-related spatial strategies for flood risk management, instead of a larger reliance on engineering infrastructure solutions.

\section{Practice}

The current ways in which resilience is being applied in practice is reviewed in the context of the 100 Resilient Cities Framework. This is accomplished through reviewing the 100RC framework and the position of the Chief Resilience Officer. In doing so, this establishes a baseline for how the Framework can incorporate rhetoric surrounding resilience within its guidelines.

\section{Resilient Cities}

The 100 Resilient Cities (100RC) was created by the Rockefeller Foundation in 2013. In brief, the mission of the Rockefeller Foundation since 1913 has been to promote the well-being of humanity around the world with partners and grantees (Rockefeller Foundation, n.d.). The ambition of the 100RC is to "help cities around the world become more resilient to the physical, social, and economic challenges that are a growing part of the 21 st century" (100RC, n.d., para. 1). This network of cities has access to the following resources:

- Financial and logistical guidance for the establishment of a new municipal governance position (a Chief Resilience Officer);

- Support for the development of a Resilience Strategy; 
- Access to partners that can assist in the development and implementation of a Resilience Strategy; and

- Membership to a global network of cities to learn from and assist.

What started off with a group of 32 cities in December 2013 grew into a network of over 100 cities by 2016 . The organization defines urban resilience as "the capacity of individuals, communities, institutions, businesses, and systems within a city to survive, adapt, and grow no matter what kinds of chronic stresses and acute shocks they experience" (100RC, n.d.). Chronic stresses are defined as slow moving disasters that weaken the fabric of the city, while acute shocks are sudden, sharp events that threaten a city.

The introduction of this model to municipal governance is of vital importance, as there has been a focus on resistance and control when addressing complex problems such as the impacts of natural disasters (Lister, 2016). This model has the potential to influence the decision-making process when addressing city-wide impacts. Moreover, it can also introduce an opportunity to introduce change at the municipal scale by means of using dimensions and drivers of resilience to inform planners and policymakers in their decisions (Empey, 2017).

\section{Chief Resilience Officer}

In order to assist cities in their mission to increase resilience as well as address shocks and stressors, the RC100 model provided funding for the creation of a new municipal governance position. This position is named the Chief Resilience Officer 
(CRO), and it is intended to act as a top-level advisor that reports directly to the city mayor (100RC, 2015). The primary task of the CRO is to establish a vision of resilience for the municipality. The CRO is tasked with establishing increased communication between the systems and actors that comprise a city (such as government agencies, local businesses and offices of international organizations), and ensuring that the municipality is engaging with other cities in order to uncover what solutions have worked in the past and how they can be modified to be suitable for the present municipality. The model also states that the following requirements of the $\mathrm{CRO}$ are fundamental for the development of an improved urban resilience:

1. Works across government department to help a city improve internal communication, address its own complexities, and foster new collaborations;

2. Brings together a wide array of stakeholders to learn about the city's challenges and recruit support for individual initiatives that help the city build resilience;

3. Leads development of the City's Resilience Strategy, that unites the city's key resilience challenges and opportunities, and spurs the city to act on them; and

4. Ensures the municipality applies a resilience lens in its discussion, that resources are leveraged holistically and projects planned synergistically.

As identified by Empey (2017), the immediate role of the CRO is to engage across all hierarchical levels within the governance structure of a municipality as well as the public and private sectors in order to guide the formation of the Resilience Strategy. 
There are certain challenges that the Strategy will be exposed to in Toronto. For instance, since natural disasters such as flooding are susceptible to interjurisdictional spread, it can be challenging to address such a shock through a municipal approach. Additionally, the Strategy alone only serves as a guideline for how a city should proceed to address resilience. However, this poses as an opportunity to involve the tools made available by land use planning in order to achieve a regulatory legal framework such as through the incorporation of resilience guidelines into the Official Plan. The position of the CRO also offers a chance to involve a collaborative effort with the public, stakeholders, and government officials through a goal-oriented approach to resilience building.

\section{Policy Scan}

The policy scan that was performed for this research focused on how Toronto is currently implementing the management of storm and rainwater through the lens of resilience. In the face of natural disasters that Toronto has faced, flood adaptation has played a large role in a recovery effort such as in the events of the historic flooding that followed Hurricane Hazel in the GTA. This policy scan showcases the potential of tools that the Toronto Resilience Strategy is able to work with in order to advance flood protection strategies. The starting point was the study of the Official Plan, Toronto Water Strategy, and Ontario Ministry of the Environment (MOE) Provincial Stormwater Management Planning and Design Manuel (see Figure 6). Applicably, these frameworks are the most important and relevant to enhancement of strategic city planning for resilience and water management. The OP defines development priorities for the City of 
Toronto, and has created specific tools such as the

Toronto Green Standard, Green Street Guidelines, as

well as the Wet Weather Flow Master Plan.

Meanwhile, the Toronto Water Strategy provides a

framework for how water is managed throughout the

city. The MOE Guidelines are an integral policy piece

to view as they are a new framework that the city will

have to conform to in a discussion about resilience.

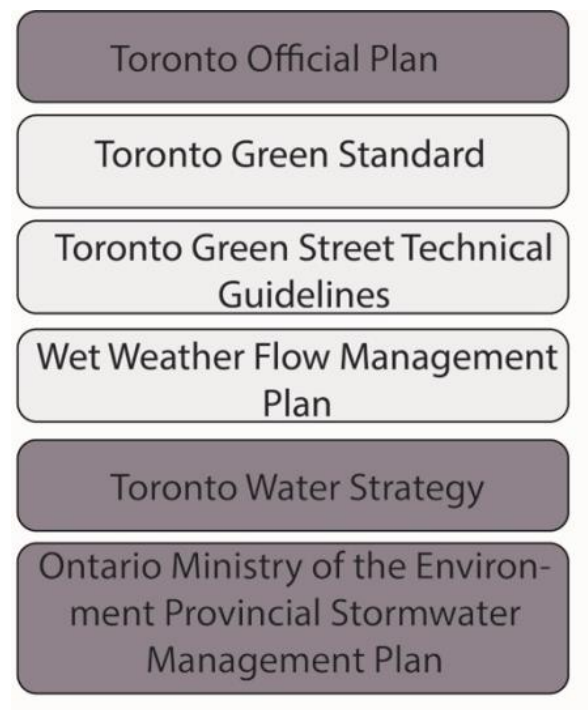

Figure 6: Visual representation of policies used in research

The aforementioned policies were scanned for language regarding applied resilience.

For the purposes of this policy scan, the definition of resilience that will be used will rely on the one provided by Lister (2016) which focuses on the tactics that planners need to engage in to attain resilience, of which is founded upon the key principles of adaptive complex systems, which are as follows:

1. Emphasis on the analysis of a water system should be placed from multiple perspectives and scales in order guarantee expert involvement;

2. Ensuring there is connectedness across scales and variance in tightness and rigidity of the feedback loop;

3. Ensure that the ecosystem is being planned for in a variety of states; and

4. Allow for diversity, plan for diversity, and understand that the result of this is a system that can be safe-to-fail; it is vital to ensure that systems can fail at small levels. 


\section{Toronto Official Plan}

The Toronto Official Plan (OP) is a municipal document that implements the Provincial Policy Statement and is provided through Section 16 of the Planning Act. As such, it is a high-level policy document and not a statute; consequently a liberal interpretation is possible. It provides goals, objectives, and policies to manage and direct physical change in order to direct physical change on the social, economic, and natural environment of the municipality. Chapters one to five of the OP provide the policies to give context and background in order to assist the effects on the social, economic, and natural environment of the municipality and were analyzed according to the framework provided for resilience.

It is important to note that the OP is grounded in principles of diversity and connectivity. In Chapter 2, it is noted how the city is part of a larger biophysical region that joins to the Oak Ridges Moraine, Niagara Escarpment, and Lake Ontario. The major watersheds of this region provide an ecological connection to many other communities that connect to downtown Toronto. Consequently, this emphasis the ecological function of the water system that is vital to Toronto as well as the surrounding municipalities.

The OP also outlines that it is vital to provide clean water as well as manage stormwater and sewage before it enters Lake Ontario. It is recommended that this can be achieved through the provision of pipes, treatment plants, and wastewater services. Additionally, it also notes that it is important to take into consideration that water conservation must begin with less water usage in homes and businesses. Furthermore, it puts an emphasis on ensuring that rainwater is absorbed where it falls, and encourages the 
use of streams and rivers to effectively control flooding, that is essential to ensure the quality of life for citizens.

The OP acknowledges that a competitive local economy and an equitable city are prerequisites for the creation of a better urban environment. It also highlights the need for an integration of transport and land use planning. Policy 2.2.2 outlines that this can contribute to "improve surface and groundwater quality and restore the hydrological function and habitat of streams, rivers, and wetlands" (Toronto Official Plan, 2015, p.25).

There are more specific policies on how the City's stormwater infrastructure is to be maintained and developed such that it supports the city-building objectives of this Plan outlined in Policy 2.2.5 by:

a) Providing facilities to support new development and maintaining the infrastructure in a state of good repair;

b) Supporting, encouraging and implementing measures and activities which reduce water consumption, wastewater and stormwater flows and improve water quality, in accordance with best management practices developed by the City for this purpose; and

c) Acquiring land or easements, where appropriate and where funds allow, to

i. Keep ravines and watercourses in a natural state; or

ii. Implement other stormwater management improvements.

In Section 3.2.3 of the OP, which focuses on Parks and Open Spaces of the Green Space System and Waterfront, there is emphasize placed on the role of the green space 
system to provide a habitat for flora and fauna and recharge the groundwater. It outlines that it is vital to think of the park system as a whole rather than a collection of parts.

\section{Toronto Green Standard}

The OP also provides specific tools to engage with stormwater management. This includes the Toronto Green Standard (TGS). The TGS was introduced in 2006 as a voluntary standard for new development and was later incorporated as a mandatory set of performance standards (City of Toronto, n.d.). It is a set of performance measures that promotes greening practices in development, which includes specific design elements such as cool roofs and cool paving; rainwater harvesting and bio-retention swales; and shade structure and trees (City of Toronto, 2008). More specific development features that target stormwater retention on development sites include targets such as:

- Retaining stormwater on-site to the same level of annual volume of overland runoff allowable under pre-development conditions;

- Retaining at least the first $5 \mathrm{~mm}$ from each rainfall through rainwater reuse, onsite infiltration, and evapotranspiration; Or

- Ensuring that the maximum allowable annual runoff volume from the development site is no more than $50 \%$ of the total average rainfall depth.

The TGS also provides guidelines on the water quality of stormwater run-off. This includes both managing and cleaning stormwater that leaves the site which would 
otherwise cause greater disruption to the surrounding water system. Specific measures include:

- Removing $80 \%$ of total suspend solids (TSS) on an annual loading basis from all runoff leaving the site based on the post-development level of imperviousness.

- Controlling the amount of E. Coli directly entering Lake Ontario and waterfront areas as identified in the Wet Weather Flow Management Guidelines.

\section{Toronto Green Street Technical Guidelines}

The Toronto OP also provides for design interventions in planning through the Toronto Green Street Technical Guidelines (GSTG). The Guidelines were released into by way of Official Plan Amendment 262 in the spring of 2016. The Amendment required a healthy natural environment, resilient infrastructure and socioeconomic systems, and a connected system of natural features. The Guidelines act as a way to increase the functionality of streets through the incorporation of green infrastructure in order to improve air quality, increase biodiversity, and manage stormwater (City of Toronto, n.d.). Green infrastructure encompasses low-impact development infrastructure which can include natural and human-made elements such as trees, green walls, and stormwater infrastructure. Historically, streets act as impermeable paved layers that increase the volume of runoff entering the municipal stormwater infrastructure. With the introduction of green infrastructure to complement or replace grey infrastructure, streets have the 
added benefit of reducing stormwater run-off (Toronto Green Streets Technical Guidelines, 2017).

The Guidelines provide for specific ways to address air quality; green house gas emissions/ energy efficiency; water quality, quantity and efficiency; ecology; and, solid waste. The Guidelines advocate for a Low Impact Development practice in the form of bioretention in order to provide for temporary storage, filtration, and infiltration of stormwater runoff. More specific practices of bioretention facilities which are suitable for specific site conditions include the following:

- Bioretention/stormwater planters;

- Bioretention curb extensions/bump-outs;

- Bioretention cells;

- Rain gardens;

- Bioswales; and,

- Pervious pavement.

The Guidelines offer strategies to address where the green infrastructure options can be placed on specific types of streets, ranging from downtown main streets to residential lanes.

The Wet Weather Flow Master Plan

A specific target for the City has been the Wet Weather Flow Master Plan (WWFMP), which protects the environment and water quality in stormwater in the Lake, rivers, streams, and other water bodies. First released in 2003, the WWFM Guidelines 
provide guidance on stormwater management requirements for both new developments and redevelopments and aimed to improve the ecosystem health of the urban watersheds (City of Toronto, 2017). When the Plan was first introduced by City Council, it was a 25year implementation plan released that was valued at \$1-billion. It targeted identifying projects and initiatives for implementation in five year periods. The WWFMP has encompassed the prioritization of stormwater controls such as source controls, conveyance controls, and end-of-pipe projects. Additionally, it has initiated a basement flooding protection program as well as a public education and outreach strategy.

The Plan targeted source controls initiatives in order to manage rain where it falls and reduce stormwater runoff volume. This targets the origin of the stormwater flow, such as roofs, roads, and driveways, before its entrance into the sewer system (City of Toronto, n.d.). This method targets the reduction of stormwater flow before it enters sewer pipes (City of Toronto, n.d.). Not only would this improve water quality in urban watercourses, it would also reduce stormwater impacts on infrastructure that contributes to basement flooding. The two main source controls initiatives that were introduced are the Mandatory Downspout Disconnection (MDD) Program and Wet Weather Flow Management Guidelines. The MDD Program encouraged City Council to adopt an amendment to the Toronto Municipal Code which required a city-wide disconnection of downspout from buildings to the municipal sewer system. Computer simulation modeling estimated that a minimum of 70 percent of houses in a given watershed must be disconnected from the storm sewer system for a significant reduction in stormwater volume inflow to be achieved (City of Toronto, 2017). The Program has proven highly 
successful, with a rate of disconnection at $79 \%$ achieved by means of education and outreach efforts, and minimal enforcement.

Conveyance controls were also championed by the Plan, and act to reduce the quantity of stormwater runoff that enters the municipal sewers through ground infiltration and evapotranspiration. The City defines such methods as those that "convey", or move the stormwater, such as sewer pipes, to the point of discharge (City of Toronto, n.d.). Interventions included the placement of green infrastructure technologies such as pervious storm sewer pipes, bio-retention units, and green bio-swales. Specific demonstration projects include the Queensway Sustainable Sidewalk, Keele Street Bioretention Infrastructure, Coxwell-Fairford Bioretention Parkette, and the Hog's Hollow Road and Stormwater Management Improvements Project (City of Toronto, 2017).

Lastly, the Plan also implemented end-of-pipe controls which strive to provide storage and/or treatment prior to stormwater being discharged to receiving surface waters from the municipal sewer system. This method targets treatment prior to stormwater entering a body of water (City of Toronto, n.d.). Specific examples of end-of-pipe facilities include green facilities such as stormwater ponds and constructed wetlands, sewer overflow treatment facilities, underground storage facilities, combined sewer overflow treatment, and stormwater overflow treatment facilities. The combined sewer overflow treatments created a reduced stormwater and CSO discharges to the Don River, Taylor-Massey Creek, and Toronto Inner Harbour. Additionally, the end-of-pipe controls spurred a project to prioritize and undertake sediment rehabilitation and cleaning projects for municipal stormwater management wet ponds. 


\section{Analysis of OP and relevant policies}

Consequently, the OP does include tactics that planners need to engage in for resilience to occur. There is a discussion of the importance of the water system from an ecological, infrastructural, and transportation perspective. Additionally, there is the notion that the natural system is spread across the city and region which allows it to have a level of connectedness in tightness and rigidity. The OP also allows for the incorporation of specific tools that target stormwater management. These tools are diverse in nature, and range from including performance standards for ensuring greening practices in new developments through the Toronto Green Standard, to guidelines for Toronto Green Street Technical Guidelines which promote the inclusion of green infrastructure to complement and/or replace grey infrastructure, and more specific stormwater controls that are offered through the Wet Weather Flow Master Plan. This showcases that concepts of resilience are targeted across a variety of states and diversities (such as streets, new developments, and stormwater controls). However, the policies could involve incorporation of how the rhetoric of resilience must be incorporated to address seasonal changes, as well as a greater explanation of how diversity could be incorporated to draw out how resilience strategies are safe-to-fail.

\section{Toronto Water Strategy}

Released in April 2018, the Downtown Water Strategy is one of five strategies that focuses on prioritized infrastructure investment of the Downtown Plan. The boundaries of this area are defined by Bathurst Street to the west and the Don River from the east, and from the waterfront to the south to the CP Rail Corridor/Rosedale Valley 
Road to the north. It is part of a 25-year vision that works towards ensuring that the development of Downtown Toronto incorporates appropriate investment in water supply, wastewater, and storm water infrastructure. There is recognition that the increased height and density of proposed developments is placing stress on the existing municipal water system.

Throughout the plan, there is emphasis on the current grey infrastructure throughout the city, and on the updates required to manage water with increased population growth. This can be seen in how priorities are placed towards addressing water main system delivery and the consequent upsizing of water mains. This is targeted for infrastructure upgrades to have a full life cycle under ideal conditions so that full economic efficiencies are achieved. The Strategy states that there is a need for increased collaboration between Toronto Water and City Planning should work together in order to optimize infrastructure upgrades. For these upgrades, it is noted that the population and employment forecasts showcased in the Provincial Plan for the Greater Golden Horseshoe (2017) are important to take into consideration, as they provide the ability to analyze the capacity of water and wastewater infrastructure for the accommodation of future growth. However, the Water Strategy also states that it is also equally important to consider the engineering factors involved in upgrading water infrastructure to ensure longevity of the life-cycle.

Additionally, there is also a priority on fixing undesirable infiltration and inflow of groundwater and stormwater in the Scott Street Sewage Pumping Station service area (Downtown Water Strategy, 2018). The results from this are to be considered in a future basement flooding protection program study so that the implementation of sewer upsizing 
and infiltration can be increasingly adaptable to potential flooding issues. This shows that there is consideration of ensuring that connectedness occurs across scales.

Overall, the Toronto Water Strategy provides a robust framework for water management guidelines for downtown Toronto. There is emphasis placed on achieving an interdisciplinary conversation between engineering, Toronto Water, as well as City Planning in order to have a successful implementation of objectives. In doing so, it is highlighted that an analysis of a water system is addressed from multiple scales and that the role of the expert is incorporated. However, there is limited emphasis placed on ensuring that the ecosystem is planned for in a variety of states. There is also room for ensuring that the ecosystem plans for diversity in order to ensure that a system can be safe to fail.

\section{Ontario Ministry of the Environment (MOE) Provincial Water Guidelines}

The Ministry of the Environment and Energy earns its legislative authority to manage water primarily from the Ontario Water Resources Act and the Environmental Protection Act (Ministry of the Environment and Energy, 1994). This provides the authority for the Ministry to regulate water supply and to control sources of water pollution through the creation of objectives that can later be incorporated into control documents that are legally binding. These considerations apply to local site specific situations, watersheds, and the Great Lakes system, ensuring that there is connectedness across scale. The objectives primarily focus on giving direction to manage the quality and quantity of surface and ground water within the province. 
More specific outlines on how groundwater and stormwater should be managed are provided through the Guidelines. There is direction provided on how groundwater and stormwater should be managed in regards to stopping or controlling leakage in construction projects, contamination of water as it impacts aquatic species, and sets out guidelines related to drinking water supplies. This demonstrates that there is emphasis placed on analyzing the water system from multiple perspectives.

General Narrative Objectives and Provincial Water Quality Objectives (PWQOs) outline the substances and materials that are tolerable to human, animal, and recreational uses. The General Narrative provides a description of how groundwater and stormwater should be managed, while the PWQOs set out a more specific guide to particle targets found within water. What could make this stronger in terms of its relation with applied resilience as defined by Lister (2016) is the inclusion of guidelines that account for seasonal changes, because as the guidelines exist right now there is little inclusion of the variability that water systems could face throughout the year. Recently, there has been a proposed new stormwater management requirement proposed by the MOE. These requirements focus on the management of runoff volume control to manage discharge of stormwater from development sites into downstream drainage systems. It will be vital to ensure that the new guidelines are included into a discussion surrounding water management.

In summary, the MOE Guidelines provide for a strong outlook on applied resilience. It is ensured that an analysis of a water system is addressed from multiple scales through an emphasis on viewing construction projects, contamination of water as it impacts aquatic species, and drinking water supplies. The Guidelines demonstrate 
connectedness across scales through their application to both local watersheds as well as the Great Lakes system. There is limited emphasis placed on ensuring that the ecosystem is planned for in a variety of states. However, there is an allowance for how diversity is planned for in a diversity of states which can be seen in an allowance to providing for the spectrum in particle targets that are found in drinking water.

\section{Summary of Policy Scan}

Overall, the policy scan showcased that there is a strong foundation of planning policy which focuses on stormwater management that the RC100 is able to use as a portfolio of influence in Toronto. It also depicted that the planning policy that was chosen for this research already includes a strong narrative of resilience. The Official Plan, and its provided policies (such as the TGS, Green Street Technical Guidelines, and WWFMP), showcase all identified key principles of adaptive complex systems. Meanwhile, the Toronto Water Strategy and MOE Guidelines both lack the inclusion of ensuring that the ecosystem is planned for in a variety of states. Additionally, the Toronto Water Strategy does not include rhetoric surrounding diversity in order to ensure that the system can fail at small levels. Please see Figure 7 for a detailed policy matrix. 


\begin{tabular}{|c|c|c|c|c|}
\hline & & $\begin{array}{l}\text { Official Plan } \\
\text { (as well as Toronto } \\
\text { Green Standard, } \\
\text { Toronto Green Street } \\
\text { Technical Guidelines, } \\
\text { Wet Weather Flow } \\
\text { Management Plan) }\end{array}$ & $\begin{array}{l}\text { Toronto Water } \\
\text { Strategy }\end{array}$ & $\begin{array}{l}\text { Ontario Ministry } \\
\text { of the } \\
\text { Environment } \\
\text { Provincial } \\
\text { Stormwater } \\
\text { Management } \\
\text { Planning and } \\
\text { Design Manuel }\end{array}$ \\
\hline 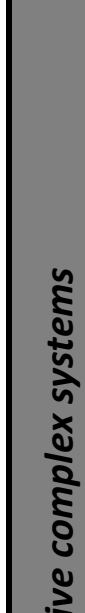 & Multiple scales and perspectives & $\begin{array}{l}\text { Diverse tools target } \\
\text { stomwater } \\
\text { management } \\
\text { from various scales and } \\
\text { perspectives, which } \\
\text { ranges from including } \\
\text { performance standards } \\
\text { for new developments, } \\
\text { guidelines for streets, } \\
\text { and stormwater } \\
\text { controls. }\end{array}$ & $\begin{array}{l}\text { The importance of } \\
\text { the intersection of } \\
\text { various perspectives } \\
\text { is stressed, such as } \\
\text { the current } \\
\text { municipal grey } \\
\text { infrastructure, water } \\
\text { main system } \\
\text { delivery, and future } \\
\text { employment } \\
\text { forecasts. }\end{array}$ & $\begin{array}{l}\text { Management of } \\
\text { groundwater and } \\
\text { stormwater is } \\
\text { placed on multiple } \\
\text { perspectives of } \\
\text { possible impacts } \\
\text { such as } \\
\text { construction } \\
\text { projects, aquatic } \\
\text { species, and } \\
\text { drinking water } \\
\text { supplies. }\end{array}$ \\
\hline 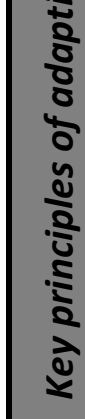 & $\begin{array}{l}\text { Connectedness across scales and } \\
\text { rigidity of feedback loop }\end{array}$ & $\begin{array}{l}\text { Notion that the natural } \\
\text { system is spread } \\
\text { across the city and } \\
\text { region. }\end{array}$ & $\begin{array}{l}\text { Connectedness is } \\
\text { achieved through } \\
\text { an interdisciplinary } \\
\text { conversation } \\
\text { between } \\
\text { engineering, Toronto } \\
\text { Water, as } \\
\text { well as City Planning. }\end{array}$ & $\begin{array}{l}\text { Guidelines include } \\
\text { an application to } \\
\text { both local } \\
\text { watersheds a well } \\
\text { as the } \\
\text { Great Lakes } \\
\text { system. }\end{array}$ \\
\hline & $\begin{array}{l}\text { Ecosystem is planned for in variety } \\
\text { of states }\end{array}$ & $\begin{array}{l}\text { Ecosystem is planned } \\
\text { for in ecological, } \\
\text { infrastructural, and } \\
\text { transportation } \\
\text { perspective. }\end{array}$ & & \\
\hline & $\begin{array}{l}\text { Allow for diversity and ensure that } \\
\text { system can fail at small levels }\end{array}$ & $\begin{array}{l}\text { Policies could involve } \\
\text { further rhetoric } \\
\text { on how diversity could } \\
\text { be incorporated to } \\
\text { address seasonal } \\
\text { changes, as well as } \\
\text { address how strategies } \\
\text { are safe-to-fail. }\end{array}$ & & $\begin{array}{l}\text { A spectrum of } \\
\text { particle target } \\
\text { allowance that } \\
\text { can be found } \\
\text { in drinking water is } \\
\text { provided. }\end{array}$ \\
\hline
\end{tabular}




\section{Role and Impact of the Chief Resilience Officer}

The CRO has the incredible opportunity to bridge the theoretical concepts as well as practical and empirical evidence of resilience as it pertains to natural stressors such as flood management and professions such as land use planning. Instead of using the traditional policy approach of resistance and control when it comes to addressing resilience, the $\mathrm{CRO}$ can initiate emerging policies in design and planning that address ecological resilience concerns. In doing so, the CRO draws attention to the economic, social, and environmental costs of severe shocks that a city faces, and the implications that this has on governance.

Consequently, it will be important to build upon any older outlooks when it comes to addressing new problems of resilience. A potential challenge that the $\mathrm{CRO}$ might come across in addressing this is the silos that exist in governance. This is a common experience that has been identified by Louise Bradette, Katherine McPherson, and Elliott Cappell in interviews. It is vital for the CRO to engage in a Resilience Strategy that tackles organizational restructuring to successfully intertwine the activities of multiple departments throughout a municipality. Additionally, it will be important for the CRO to employ a vision of resilience that addresses the tactics that planners need to engage in to attain resilience, of which is founded upon the key principles of adaptive complex systems. Within the City of Toronto, there is already a strong foundation within policy documents for a design approach to resilience in the official policy documents, that provide a good example for the work that the CRO can gain inspiration from and potentially make improvements to. 
Elliott Cappell identified that defining success in his position relies on "getting people to work together that generally don't work together" (Personal communication, 2018). To achieve this, it was noted that it would be necessary to break silos that exist within the existing structures of governance to identify and support strategic issues. Historically, stormwater management has largely been addressed by the Water Department, and has also received input from the Planning Department as illustrated through the planning policy scan. It will be important for future discussions, plans, and implementation measures to include knowledge, expertise, and tools provided by both the Water Department and Planning Department. With his mandate of collaboration, the CRO has the potential to achieve such a task (illustrated in Figure 8).
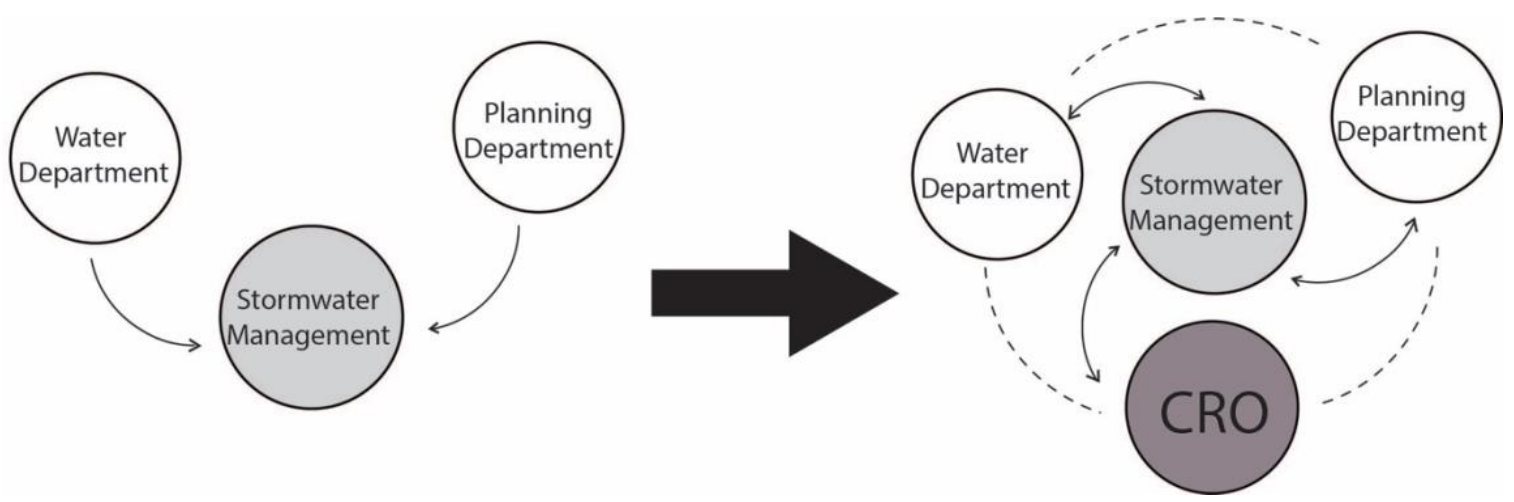

Figure 8: Proposed strategy for collaboration and structure

One of the ways that the RC100 Office has already made an impact in the beginnings of his term is applying for a federal grant which is targeted towards the climate change revitalization. This grant was successfully won. Additionally, the RC100 has started a committee that strives to bring various perspectives from different 
departments within the city together. It was noted that the Chief Planner will be holding a place on this committee, which will be instrumental in bringing in a land use planning perspective to water management strategies. Overall, it was noted that it will be important for this position to leave a legacy of future decision making in municipal decision making within the City of Toronto.

The future work of the CRO when it comes to addressing the shock of flooding in Toronto can be furthered through the policy scan outlined by this MRP. There is already an abundance of tools that have been created in Toronto that are targeted towards stormwater management improvements (such as the Toronto Green Standard, Toronto Green Street Technical Guidelines, and the Wet Weather Flow Master Plan). Such policies provide an important means to identify a portfolio of influence for the Toronto RC100 Office. For example, the aforementioned policies currently act solely as guidelines, and do not have legislative teeth. A target that the CRO could work towards in achieving during their term could be the ensuring that policies such as the WWFMP pass legislature.

\section{Findings}

The findings focus on addressing the research objectives identified in the beginning of this paper through data retrieved through qualitative interviews. They are created in sections that focus on the context in Toronto, followed by lessons that can be learned from the work of CROs in Montreal and Vancouver. The subject matter that the conversations focused on revolved around the following questions: 
1. Who do you work with?

2. What are the ways that your office is working to improve water management techniques?

3. How does your office intersect with the Planning Department?

4. What role do you see for urban planning in relation to the Chief Resilience Officer?

Throughout the discussions, there was prominence placed on understanding the flooding and water management strategies that are being developed through the RC100 office and how they interest with land use planning.

\section{What is the City of Toronto doing?}

During the time period of June to December 2017, the City of Toronto was in its Preliminary Assessment Phase in identifying the shocks and stresses that the City faces. Factors that assisted the City in identifying these symptoms included research and pressing urban issues. When the RC100 team spoke with City of Toronto employees, what became evident was that the City had a great concern over the recent shocks that the City faced - in particular, there was a strong preliminary concern surrounding climatic issues. It was identified that Toronto does not have an up to date climate change plan and that its biggest issue is addressing flooding.

As it pertains to flooding, there are three lenses that historic flooding can be viewed through. These three lenses are ravine, fluvial, and basement flooding. The biggest ravine flooding in Toronto's history was the 1954 Hurricane Hazel event, which caused the first big resilience initiative in the city. This brought a change to the land use 
planning framework in Toronto through the incorporation of ecosystem management following extreme ravine flooding throughout the GTA. Since then, there has been growing attention given to the question of how flooding can be managed through land use planning tools.

Fluvial flooding, which causes a river to exceed capacity can be caused by increased rainfall and/or heavy snow melt over short periods of time, is also of increasing importance to Toronto. The fluvial flooding event of 2013 caused significant damage to the city, with drastic municipal economic and insurance loss of over $\$ 4.9$ million (City of Toronto, 2013). A major connection made between ravine and fluvial flooding has been the impact on citizen well-being and municipal infrastructure as it relates to basement flooding. Increased risk of ravine and fluvial flooding not only causes increase in municipal and residential insurance costs, but it also affects the urban life quality of urban homeowners and renters.

The most recent flooding event which has caused Toronto great concern has been increased lake level rise. During the summer months of 2017, water levels hit a hundredyear record high in the summer months, that had great effects on the entire length of the waterfront. The Toronto Island Park had suffered significant consequences from these events, which resulted in over 800 residents, almost 30 businesses, and two schools having to adapt to rising water at a net financial impact of approximately $\$ 4.8$ million (City of Toronto, 2017). The Chief Resilience Officer of Toronto identified that the water flow between the Great Lakes has been a contributor to increased flooding events, and that there could possibly be a correlation with how water dams are managed. 
In order to address these events, the CRO identified that Toronto should first look to lessons that can be learned from other cities. During the ULI discussion, the case of New York City was brought up. The most efficient way to protect the city from flooding would be to engineer a giant wall that would also double as a park. A similar construction could be considered beneficial for Toronto, because it could connect to the Toronto Islands and prevent future instances of lake level rise to areas that have been prone to flooding.

The shock of flooding could also be addressed through further engagement from other industries. Cappell identifies that it could be helpful to learn from "smart cities" initiatives targeted towards flooding, which are proposals intended to improve lives of residents through innovation, data, and technology. On this note, it was identified that the sewer capacity of downtown Toronto should also be considered to see how it can impact speed of construction growth in the city. Since new development will cause further strain on the existing sewage system, a potential consequence can result in sewers running over capacity. This is because an increase in new development is correlated with an increase in impervious surface, which increases stormwater runoff rates and consequently places greater strain on existing stormwater sewers. See Figure 9 for a visual representation (City of Ridgeland, n.d.) During the ULI discussion, it was identified that the current number of high rise buildings proposed in downtown Toronto is more than San Francisco and Madrid combined. This presents the notion that there could be a correlation between the number of highrises proposed, the physical infrastructure of the city, and the potential for increased stormwater flooding. 


\section{NATURAL vs. URBAN STORMWATER DRAINAGE}

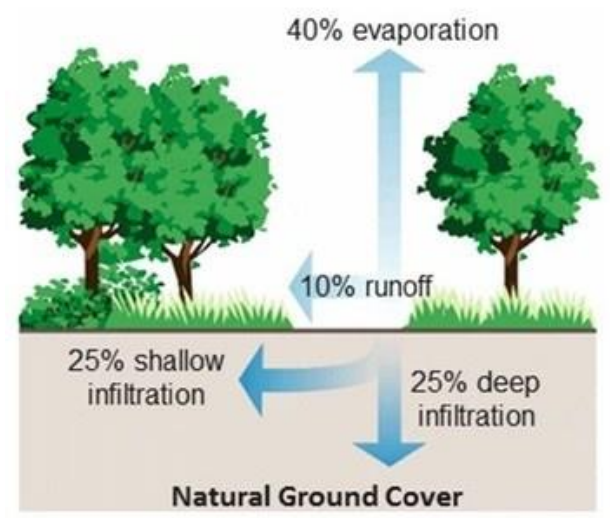

Stormwater infiltrates into the ground Plants and trees work to absorb stormwater

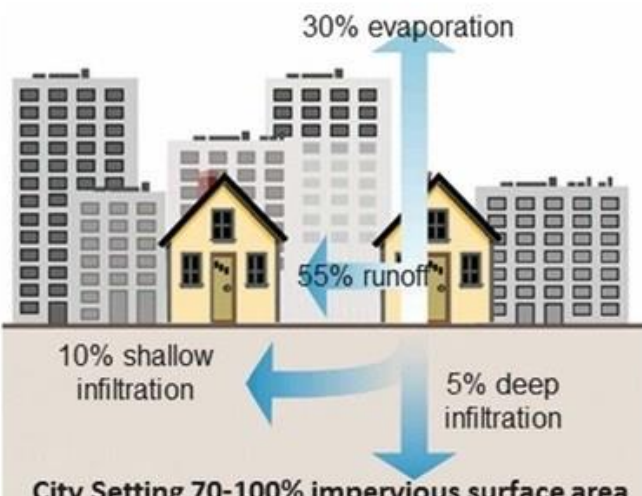

City Setting 70-100\% impervious surface area

Water hits impervious surface and runs off roofs, streets, parking lots etc. Runoff goes into the sewers

http://wmwnrcs.usda.gov/wps/portal/nres/detallfull/national/technical/alphabetical/water/restoration/?\&cid=nrcs143_026903

Figure 9: Illustration of natural and urban stormwater drainage

\section{What lessons can be learned from other cities?}

When interviewing the CROs of Montreal (Louise Bradette) and Vancouver (Katherine McPherson), it was evident that water management is identified as a shock that needs to be addressed by the Resilience Strategy. This was vital to gaining national perspective to what resilience events Canadian cities are addressing. Both Montreal and Vancouver have identified that stormwater management is a priority that needs to be addressed. By reviewing the ways that these two cities are targeting this problem, Toronto is able to draw inspiration for what can be done to tackle its very own stormwater management problem. 


\section{City of Montreal}

In the City of Montreal, Louise Bradette identified that emergency planning plays a key role in her work as a Chief Resilience Officer. In fact, she works closely with an emergency planner on the key area of infrastructure protection. The work of the Resilience Strategy not only focuses on the city of Montreal, but also the surrounding agglomeration of cities and boroughs. The CRO agenda involves other municipal departments including health, fire, and police. In this sense, it is important for the CRO to establish efficient communication with the actors. While railway safety is at the forefront of the Resilience Strategy in Montreal, there is also significant emphasis on flood management.

The CRO of Montreal also works closely with the municipal planning department. From an emergency measure perspective, it was identified that a major constraint is risk assessment in land use planning. Consequently, the Montreal RC100 Office is currently working with the planning department in order to take into consideration that a subsequent evolving conversation must take place in order to ensure that the appropriate land use tools are created/incorporated in order to support the objectives of the Resilience Strategy. It was noted that the role of residents is also important to be brought into a conversation about resilience and the role of land use planning.

Improving water management techniques is also at the forefront of the work that the Resilience Strategy is addressing. With historic flooding of the des Prairies River along the northern edge of Montreal in April 2017, there has been a push to have the issue of flooding be addressed through land use planning (Gyulai, 2017; Bradette, 2017). Bradette identified that this can be completed through issuing a new report on the 2017 
flooding to draw to light the issues that the city faces and to gain a better perspective on what can be done next time such a flooding event would occur. In January 2018, the RC100 Office was working to put together a Green and Grey Infrastructure Committee in order to bring various departments within the city together to have a conversation about what tools can be used from various disciplines in order to address flooding.

It was specified that within land use planning, it would be important to create new mapping that highlights flood-prone areas, as the city is currently working with 2006 mapping flood data. Furthermore, it was identified that there is a relation between development in Montreal and what can be achieved with resilience and flooding initiatives. It was noted that since the city is largely developed, this brings about a significant amount of challenges. More specifically, because the central business district was constructed around railways and industrial lands there are significant risk management threats to regulation. An agreeable balance between the social, economic, and land use development and risk management must be achieved.

When addressing the future and initial risk of flooding and railway construction, there is a need for backup zones. Such zones would allow for control of risk, and would be beneficial to be placed around railroads and new development. Such a regulation would leave a great legacy in Montreal. This could be modeled after the approach of a risk generator, which is present in several European cities, however does not exist in Canada.

During the qualitative interview, it was identified that long term thinking should be incorporated into the municipal decision making process. Since the position of the CRO is funded for three years by the Rockefeller Foundation in Montreal, it will be vital 
to ensure that a legacy of resilience thinking is left behind in future municipal decisions. In order to ensure that such a legacy is delivered, Bradette stressed it is important to start with the citizen first. What is meant by this is that a citizen who is more informed of resilience initiatives is more likely to get involved in the actions that support the initiatives. In order to accomplish this, strong governance is needed in order to ensure that resilience initiatives are the combined efforts of a range of people, which includes a range of people, from government to employees and more importantly residents, not just the responsibilities of the fire and police officers.

\section{City of Vancouver}

In a best practice interview with Katherine McPherson, it was identified that it is important for her office to leave a legacy that empowers municipal staff to understand the importance of a grassroots movement in such a strategy when it comes to addressing water management. Overall, it was identified that there is a large priority placed on seismic policy planning as well as rain water management in the work of the Vancouver Resilience Strategy. It was deemed vital to ensure that there is an intersection between the tools offered by land use planning and the work that the CRO is striving to achieve.

One of the biggest natural shocks that Vancouver faces is seismic activity. Consequently, there is emphasis placed on new building development and seismic risk surrounding neighbourhood residence capacity. Since earthquakes are the biggest unmitigated risk for the city, there is more prominence placed on addressing this shock for the Green City Strategy Team, which means that the team works more closely with sustainability and community emergency preparedness. 
While there is a seismic lens to the Resilience Strategy of Vancouver, there is also emphasis on water management. Vancouver is considered a rainy city - in fact, in November 2017 the city received rain on 27 out of the 30 days in the month (Judd, 2017). There is a matrixed approach to water management that Vancouver RC100 Office strives to achieve. As the Vancouver CRO, Katherine McPherson has the authority to advise on the Rainy City Strategy, which is geared towards water management (City of Vancouver, 2017). More specifically, this strategy encompasses the management of grey and green infrastructure. One of the objectives that Katherine McPherson is looking to achieve is to communicate the risk of water scarcity to residents, that she hopes to draw attention to the concept that rainwater needs to be captured and treated as a valuable resource that residents can tap into.

McPherson also identified that coastal flooding is also of importance to the intersection between the Resilience Strategy and water management. Through this, it was identified that this initiative needs to be city wide. While historically such an initiative has been left to Engineering Services to take on, there is now a bigger push for the city planning to take on a role. The Vancouver Planning, Urban Design, and Sustainability office has a great potential to create a lasting benefit to rainwater, water run off, and coastal flooding practices through zoning and development policies. Additionally, municipal planning in Vancouver has the power to provide a legal framework to RC100 objectives through the legal framework afforded through Community Plans.

Overall, the Vancouver CRO strives to build a legacy of strategic integration of resilience into municipal decision-making across various city departments. The objective of the Resilience Strategy is that it is not to be read as a stand-alone document. Rather, it 
should be considered in conjunction with other documents such as the Healthy City Strategy, and Community Plans. Such a task would create an integrative platform and require support staff, and weaving resilience efforts into the municipal operating budget. It was highlighted that the $\mathrm{CRO}$ has a strong relationship with the University of British Columbia and Simon Fraser University, and is also involved in grassroots community groups, and neighbourhood programming. Such involvement of the CRO achieves the objective of working across all levels of the conversation within a municipal hierarchy.

\section{Recommendations}

Currently, the Chief Resilience Officer of Toronto is in the early stage of forming a Resilience Strategy for the City of Toronto. Through conducting qualitative interviews with the CROs of Montreal, Toronto, and Vancouver and performing a policy scan on water management strategies in Toronto, an analysis of the objectives is provided which presents recommendations for the development of the Toronto Resilience Strategy.

\section{Objective \#1: Understand the role of the RC100 Office and its intersection with stormwater management in the City of Toronto}

There is emphasis on addressing ecological resilience and its intersection with stormwater management in the preliminary stages of Toronto's RC100 Framework. There is a robust awareness of historic events, such as the reaction that land use planning had to the flooding which followed Hurricane Hazel in 1954. Throughout discussions with Elliott Cappell, it was identified that there is attention to the fact that the identified 
shocks that Toronto faces will not be fixed with the assistance of a single department. In order to address the issue of flooding, it is vital that there is attention divided to the issue from the various lenses that flooding originates from. This ranges from basement flooding to lake level rise. The $\mathrm{CRO}$ readily acknowledged that this problem has historically been left to silos in governance. In order to address this, the CRO will have to ensure close collaboration in decision-making with various municipal departments and ensure that important perspectives from stakeholders are brought in. Such a task will be furthered through interjurisdictional cooperation and municipal structural re-organization in order to empower decision makers in collaborative strategies for resilience. More specifically it will require a conversation between major municipal department stakeholders, which includes the municipal planning department due to the potential longevity that such tools can offer, such as introducing updated zoning bylaws that appropriately reflect built form and flooding potential.

\section{Objective \#2: Identify potential tools that the Toronto Resilience Strategy can work with}

While the RC100 Office is a new position in Toronto, it has an assortment of tools that Toronto can work with when it comes to addressing resilience and water management. Through the policy scan, it was proven that there is a strong foundation of applied ecological resilience when it comes to water management in Toronto, that is exhibited in the Toronto Water Strategy, Ontario Ministry of the Environment and Climate Change, and City of Toronto Official Plan.

The Toronto Water Strategy places emphasis on the fact that water management should work together with Toronto Water and City Planning in order to optimize 
infrastructure upgrades. There are also ongoing considerations provided for a future flooding protection program study, which aligns with the plans of the Toronto RC100 Office to address water management in Toronto.

The Ontario Ministry of the Environment and Climate Change provides a discussion on how groundwater and stormwater should be managed, with varying emphasis placed on analyzing the water system from multiple perspectives. It will also be important to ensure that there is attention given to emerging trends such as new stormwater management guidelines that are to be released.

There is already a significant amount of rhetoric surrounding resilience and stormwater management practices written into the Toronto OP and the policies that it allows for. There is guidance provided on the concept that water conservation begins with an emphasis on the individual business and homeowner. The appropriate usage of streams and rivers to effectively control flooding is vital for quality of citizen life. There is also a strong connection outlined between the importance of stormwater infrastructure and how city-building objectives are outlined.

The OP also provides for a range of policies that provide regard for improving stormwater management in Toronto. Guidelines such as the Toronto Green Standard, Green Street Technical Guidelines, and Wet Weather Flow Management Plan deliver specific recommendations for how the urban fabric can be altered in order to improve stormwater circulation. The RC100 Office has the potential of strengthening these existing land use planning tools through ensuring implementation measures by means of ensuring that they are incorporated into legislation. Consequently, this would ensure that 
the tools are legally required to be enforced and therefore increase their potential for improving the implementation of stormwater management techniques.

Overall, there is a strong foundation in the outlined policy surrounding applied ecological resilience and water management. Not only are there specific planning tools, such as the OP, that contain concepts to address resilience and flooding, but there are also regional and interdepartmental policies that can be viewed. This reveals that the RC100 Office has a strong set of existing polices that can be outlined and strengthened in further stages of the Resilience Strategy.

\section{Objective \#3: Uncover what lessons can be learned from the CROs of Montreal and Vancouver}

Toronto is in the beginning stages of its Resilience Strategy, which means that it can learn from other cities that are further along in their RC100 term and consequently uncover what can be implemented to support strategic issues. Montreal and Vancouver are two major Canadian cities that also hold the RC100 Office. While the focus of their Resilience Strategies is seismic policy and railway safety, respectively, both cities have a focus on water management. In Vancouver, there is a bigger emphasis on the issue of changing the way that residents perceive rainwater and ensuring that there is education provided on the importance of reusing rainwater. Meanwhile, in Montreal it is acknowledged that updated flood mapping is required in order to ensure that flood zones are being updated in order to increase awareness of land sensitivity. Both cities identified that there is a potential correlation between new development and its impact on flooding as well as sewer infrastructure. 
Consequently, it will be important for the Toronto RC100 Office to take inspiration from the aforementioned initiatives that Montreal and Vancouver have identified to be important in addressing stormwater management. It is recommended that the Resilience Committee, which has been formed under the leadership of Elliott Cappell, consider the priorities in the intersection of land use planning, stormwater management, and the Resilience Strategy. Specifically, it is recommended that the Toronto RC100 Office place emphasis on citizen engagement in the conversation surrounding resilience and stormwater management. This would increase citizen knowledge and engagement with stormwater practices. Additionally, it is recommended that the Toronto Resilience Strategy also target updating flooding maps to showcase land sensitivity. With increased development in Toronto, it will be important to document the areas prone to flooding in order to showcase the importance of targeting stormwater management practices to climate change adaptation.

\section{Objective \#4: Provide recommendations to the Toronto Resilience Strategy}

It has been identified that there could be a potential correlation between the number of new developments within downtown Toronto and increased basement flooding. There are several ways that land use planning and municipal governance can play a vital role in addressing this issue in relation to urban water management and the Resilience Strategy.

Firstly, there is the opportunity for the City of Toronto Strategic Initiatives and Policy Analysis (SIPA) Department to support strategic issues on the relationship between flooding and increased development. In order to do this, there is a possibility to 
perform a study on the over three hundred development projects currently under appeal in Toronto. Such a study could calculate the percentage of open space as well as permeable green space on sites prior to development in order to compare the corresponding statistics with what is provided on site by the new development. This would allow for the establishment of a baseline in order to monitor whether there is a correlation between future water retention on newly developed sites and stormwater flooding in downtown. Additionally, the study can also act to confirm that new development meets the guidelines of ensuring that proper green infrastructure is placed on the developed site in order to help with flood adaptation.

Such a SIPA study can also address the financing mechanisms set in place to provide funding for appropriate green infrastructure with new developments in order to ensure flood adaptation. It is important to consider what funding tools can be implemented to attain revenue for water infrastructure improvements that are required alongside with intensification of development as there are currently no mechanisms in place in Toronto. Historically, upgrades to sewer infrastructure in Toronto have been paid through water fees based on consumption (Williams, 2018). Introducing a stormwater levy that shifts costs to property owners and businesses with hard surfaces such as parking lots is one way to combat the contributing water runoff that such land services produce.

Collaboration is key. Further discussions, panels, and committees that work together on the topic of urban water management within the Resilience Strategy require cross-departmental communication within the City. Cross-pollinating between the Water Department and the City Planning Department is vital to ensure that the topic of flood 
management is not left in silos within the municipality. In order to achieve this, municipal structural re-organization could be required in order to empower decision makers to create collaborative strategies for resilience. Interjurisdictional cooperation will be instrumental in bringing about resilience strategies to fruition as the physical landscape that stormwater management affects stretches across much further than the boundaries of Toronto. On this note, it is also vital that there continues to be collaboration with educational institutions, particularly on the topic of resilience as it relates to urban water management. It is recommended that these educational institutions are professionally accredited programs, so that students can work on timely projects, and receive an opportunity to guide the toolkits, frameworks, and direction that their profession is placing forward.

\section{Conclusion}

The Toronto Resilience Strategy presents an incredible opportunity for addressing the problem of increased stormwater flooding. This is because the RC100 Office is able to bring together joint endeavors that span across municipal departments. It is vital that land use planning tools play a role in the Strategy in order for it to have a more robust legislative and regulatory nature. The CROs of Vancouver and Montreal have identified that it is crucial for land use planning to be at the forefront of a discussion that addresses how municipalities can address stormwater management in its intersection with land use planning. There is already a wealth of planning policy tools that target stormwater management in Toronto as outlined by the policy scan conducted in this paper. This 
provides a portfolio of influence for the CRO to use in addressing stormwater management practices in Toronto which can target specific future actions such as strengthening existing land use planning tools, ensuring interjurisdictional cooperation, and municipal structural re-organization to empower decision makers in collaborative strategies for resilience. 


\section{Works Cited}

Alkassim, R. S., Musa, S. A., Etikan, I. (2015, December). Comparison of convenience sampling and purposive sampling, 5(1), p. 1-4.

Barr, J., Christensen, M., \& Welch, A. (2017, March). Husserlian descriptive phenomenology: A review of intentionality, reduction and the natural attitude. Journal of Nursing Education and Practice 7(8), p. 113-118.

Berkowitz, M. (2015). What a Chief Resilience Officer Does. Received fm http://100resilientcities.org/what-a-chief-resilience-officer-does/

Bradette, L. (2018, February 13). Personal Interview.

Canadian Institute of Planners. (n.d.). Statement of Values. Retrieved from http://www.cip-icu.ca/Files/Exam-reading-list/Statement-of-Values-and-Code-ofProfessional-Pract

Cappell, E. (2018, February 14). Personal Interview.

Cappell, E. (2018, February 7). ULI Discussion.

Connecticut Department of Public Health. (2014, November). The policy scan in ten steps. Retrieved from https://portal.ct.gov/-/media/Departments-andAgencies/DPH/dph/hems/chronic_dis/PolicyScanGuideFINAL2pdf.pdf?la=en

City of Ridgeland. (n.d.). Stormwater Management Program [Online Image]. Retrieved from https://www.ridgelandms.org/city-departments/public-works/stormwater/ 
City of Toronto. (n.d.). Green Streets. Retrieved from https://www.toronto.ca/servicespayments/streets-parking-transportation/enhancing-our-streets-and-publicrealm/green-streets/

City of Toronto. (2008). Toronto Green Standard Update: Performance measures for sustainable development. Retrieved from https://www.toronto.ca/servicespayments/streets-parking-transportation/enhancing-our-streets-and-publicrealm/green-streets/

City of Toronto. (2013). Follow-up on the July 8, 2013 Storm Event. Retrieved from https://www.toronto.ca/legdocs/mmis/2013/ex/bgrd/backgroundfile-62645.pdf

City of Toronto. (2013). Impacts from the July 8, 2013 Storm Event on the City of Toronto. Received from https://www.toronto.ca/legdocs/mmis/2013/ex/bgrd/backgroundfile-61502.pdf

City of Toronto. (2013). Impacts from the July 8, 2013 storm event on the City of Toronto. Retrieved from https://www.toronto.ca/legdocs/mmis/2013/ex/bgrd/backgroundfile-61502.pdf

City of Toronto. (n.d.) Green Streets. Retrieved from https://www.toronto.ca/servicespayments/streets-parking-transportation/enhancing-our-streets-and-publicrealm/green-streets/

City of Toronto. (2015, August). Official Plan Five Year Review. Retrieved from https://www.toronto.ca/legdocs/mmis/2015/pg/bgrd/backgroundfile-83301.pdf City of Toronto. (2017, November). Toronto Green Streets Technical Guidelines. Retrieved from https://www.toronto.ca/ext/digital_comm/pdfs/transportationservices/green-streets-technical-guidelines-document-v2-17-11-08.pdf 
City of Toronto. (2017). Damages sustained from rising lake water levels and restoration plans for waterfront parks. Retrieved from https://www.toronto.ca/legdocs/mmis/2017/cc/bgrd/backgroundfile-105457.pdf

City of Toronto. (2015). Toronto Official Plan. Toronto: City of Toronto.

City of Toronto. (2018, April). Downtown Water Strategy. Received from https://www.toronto.ca/wp-content/uploads/2018/04/8e21-city-planning-tocorewater-strategy.pdf

City of Vancouver. (2017). Rain City Strategy. Received from http://council.vancouver.ca/20171101/documents/pspc5.pdf

City of Toronto. (n.d.). ResilientTO. Received from https://www.toronto.ca/servicespayments/water-environment/environmentally-friendly-city-initiatives/resilientto/

Clark, W. C., Jones, D. D., \& Holling, C. S. (1979). Lessons for ecological policy design: A case study of ecosystem management. Ecological Modelling, 7(1), p. 1-53.

Desjardins, E. (2015). Promoting resilience. The Quarterly Review of Biology, 90(2), p. $147-165$.

Duan, N., Palinkas, L., Green, C., Horwitz, S., \& Wisdom, J. (2016). Administrative Policy Mental Health, 42(5), p. 533-544.

Edwards, R. \& Holland, J. (2013). What is qualitative interviewing. Bloomsbury Academic: London.

Empey, T. (2017). A case study of 100 Resilient Cities: Does the 100 Resilient Cities model provide for a robust decision-making framework? 
Environment and Climate Change Canada. (2013). Hurricane Hazel Storm Information.

Retrieved from http://www.ec.gc.ca/ouragans-

hurricanes/default.asp?lang=En\&n=5C4829A9-1

Environment Canada. (2011). Municipal Water Use Report. Retrieved from https://www.ec.gc.ca/Publications/B77CE4D0-80D4-4FEB-AFFA0201BE6FB37B/2011-Municipal-Water-Use-Report-2009-Stats_Eng.pdf

Environment Canada. (2017). Water availability: indicator initiative. Retrieved from https://www.canada.ca/en/environment-climate-change/services/wateroverview/quantity/availability-indicator-initiative.html

Fath, B.D., Dean, C.A., Katzimer. (2015). Navigating the adaptive cycle: an approach to managing the resilience of social systems. Ecology and Society 20(2):24.

Folke, C. (2006). Resilience: The Emergence of a Perspective for Social-Ecological Systems Analyses. Global Environmental Change, 16(3), 253-267.

Gandy, M. (2002). Concrete and clay: reworking nature in New York City. Cambridge, Massachusetts: MIT Press.

Godschalk, D. (2013). Understanding the notion of resilience in spatial planning: A case study of Rotterdam, The Netherlands. Cities, 35, 200-2012.

Government of Canada. (2010). Flooding events in Canada: Ontario. Retrieved from https://www.canada.ca/en/environment-climate-change/services/wateroverview/quantity/floods/events-ontario.html

Gyulai, L. 2017. Flood watch: 'We have reached the peak,' but river along Montreal will remain high for days. The Montreal Gazette. Received from 
http://montrealgazette.com/news/local-news/flood-watch-we-have-reached-thepeak-but-river-along-montreal-will-remain-high-for-days

Isai, V. (2016). Toronto Star. Retrieved from

https://www.thestar.com/news/gta/2016/10/15/hurricane-hazel-was-torontosperfect-storm.html

Judd, A. (2017). It rained on 27 of 30 days in November, tying a Vancouver record set in 1953. Global News. Received from https://globalnews.ca/news/3892098/vancouver-rain-record-november/

Katherine, M. (2018, February 14). Personal Interview.

Kovacs, M. (2017, June). Toronto appoints its first Chief Resilience Officer. Retrieved from https://www.itworldcanada.com/article/toronto-appoints-its-first-chiefresilience-officer/394068

Lister, N.M. (2016). Resilience beyond rhetoric in urban landscapes and design. In Nature and Cities (pp. 297-319).

Ludwig, D., Jones, D. D., \& Holling, C. S. (1978). Qualitative Analysis of Insect Outbreak Systems: The Spruce Budworm and Forest. Journal of Animal Ecology, 47(1), 315-332.

Ministry of the Environment and Energy. (1994). Water Management: Policies, Guidelines, Provincial Water Quality Objectives. Retrieved from https://www.ontario.ca/page/water-management-policies-guidelines-provincialwater-quality-objectives\#section-2

Mileti, D. (1999). Disasters by design: A reassessment of natural hazards in the United States. Joseph Henry Press. 
Neuman, L., \& Robson, K. (2014). Basics of Social Research.

Peterson, G., Allen, C.R., \& Holling, C.S. (1998). Ecological resilience, biodiversity, and scale. Ecosystems, p. 183-184.

Pickett, S. T. A., \& Ostfeld, R.S. (1995). The shifting paradigm in ecology. In R.L. Knight \& S.F. Bates (Eds.), A new century for natural resources management. Washington, DC: Island Press, p. 261-278.

Pickett, S., McGrath, B. Cademasso, M.L. Felson, A. (2014). Ecological resilience and resilient cities. Building Research \& Information, 42(2), 143-157.

Resilience Alliance, n.d. Retrieved from https://www.resalliance.org/key-concepts Rockefeller Foundation. (n.d.). About Us. Retrieved from https://www.rockefellerfoundation.org/about-us/

United Nations. (2018). World Urbanization Prospects: The 2018 Revision. Received from https://esa.un.org/unpd/wup/Publications/Files/WUP2018-KeyFacts.pdf

Walker, B., \& Salt, D. (2012). Resilience practice: building capacity to absorb disturbance and maintain function. Island Press.

Williams, R. (2018, April 13). Stormwater Tax Advocated. Novae Res Urbis Toronto 22(15).

100 Resilient Cities. (n.d). Toronto's Resilience Story. Retrieved from https://www.100resilientcities.org/cities/toronto/

100 Resilient Cities. (n.d.) What a Chief Resilience Officer Does. Retrieved from http://100resilientcities.org/what-a-chief-resilience-officer-does/

100 Resilient Cities. (n.d.). About Us. Retrieved from http://www.100resilientcities.org/about-us/\#section-2 